A Report to the Upper Skagit Indian Tribe per agreement \# 17WNYD00SIT5545

Investigation of Otolith Microstructure and Composition for Identification of Rearing Strategies and Associated Baker Lake Sockeye Salmon (Oncorhynchus nerka) Smolt Production, Washington, 2016-17

Open-File Report 2021-1032 



\section{Investigation of Otolith Microstructure and Composition for Identification of Rearing Strategies and Associated Baker Lake Sockeye Salmon (Oncorhynchus nerka) Smolt Production, Washington, 2016-17}

By Kimberly A. Larsen, Lisa A. Wetzel, Karl D. Stenberg, and Angie M. Lind-Null

Open-File Report 2021-1032 


\section{U.S. Geological Survey, Reston, Virginia: 2021}

For more information on the USGS - the Federal source for science about the Earth, its natural and living resources, natural hazards, and the environment—visit https://www.usgs.gov or call 1-888-ASK-USGS.

For an overview of USGS information products, including maps, imagery, and publications, visit https://store.usgs.gov/.

Any use of trade, firm, or product names is for descriptive purposes only and does not imply endorsement by the U.S. Government.

Although this information product, for the most part, is in the public domain, it also may contain copyrighted materials as noted in the text. Permission to reproduce copyrighted items must be secured from the copyright owner.

Suggested citation:

Larsen, K.A., Wetzel, L.A., Stenberg, K.D., and Lind-Null, A.M., 2021, Investigation of otolith microstructure and composition for identification of rearing strategies and associated Baker Lake sockeye salmon (Oncorhynchus nerka) smolt production, Washington, 2016-17: U.S. Geological Survey Open-File Report 2021-1032, 15 p., https://doi.org/ 10.3133/ofr20211032.

ISSN 2331-1258 (online) 


\section{Acknowledgments}

This research was a collaborative effort between the Upper Skagit Indian Tribe (USIT) and the U.S. Geological Survey (USGS). The authors would like to thank Bob McClure (USIT) for project coordination, the USIT Natural Resources Team for providing samples, Andy Ungerer and Richard Bradshaw of Oregon Sate University's W.M. Keck Collaboratory for Plasma Spectrometry for help with the LA-ICPMS analysis, Diego Fernandez of the University of Utah's IC-PMS Metals and Strontium Isotope Facility for help with LA-MC-ICPMS, and those that helped with manuscript review. 



\section{Contents}

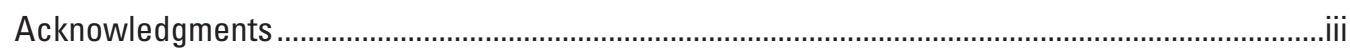

Introduction

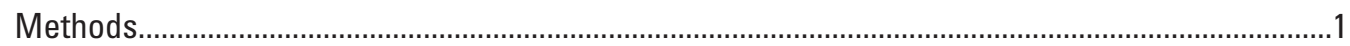

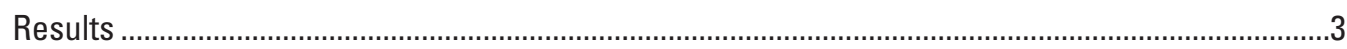

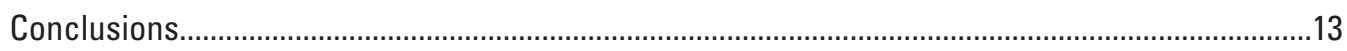

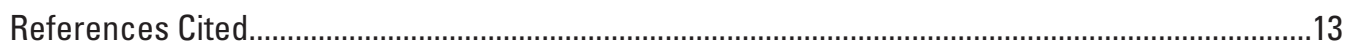

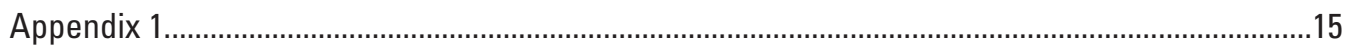

\section{Figures}

1. Magnified image showing a representative polished otolith sample, depicting the locations of laser scars and spots after microchemical analysis.

2. Magnified image showing a representative polished sockeye salmon fry otolith from the natural production group, identifying hatch check, early development check, and first feed check collected from the Baker River, Washington, March 2016

3. Magnified image showing a representative polished sockeye salmon fry otolith from the artificial spawning beach group, identifying hatch check, early development check, and first feed check collected from the Artificial Spawning Beach of the Baker River Hatchery, Washington, March 2016

4. Magnified image showing a representative polished sockeye salmon fry otolith from the artificial incubation group, identifying the hatch check, early development check, ponding check, first feed check, and the beginnings of a raceway check collected from the Baker River Hatchery, Washington, March 2016......5

5. A representative polished yearling sockeye salmon otolith from the artificial incubation (Al) group, displaying the entire otolith from core to edge, identifying the hatch check, early development check, complete raceway check, and 1st annulus collected from the Baker River Hatchery, Washington, 2017

6. Magnified image showing the same representative polished yearling sockeye salmon otolith, identifying the hatch check, early development check, ponding check, first feed check, and the complete raceway check collected from the

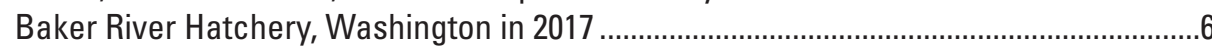

7. Box plots comparing microstructural features analyzed by production group .................7

8. A typical microchemistry transect depicting the decline in strontium-to-calcium ratios to the edge associated with high strontium levels in the maternal marine environment during egg formation and the low freshwater strontium levels during subsequent egg-to-fish development.

9. Box plots of trace element molar concentration ratios for each production group within Region A and Region B.

10. Box plots of strontium isotope ratios for each production group ...................................11

11. Canonical Analysis of Principal coordinates ordination plot showing the separation of production groups by trace elements in molar concentration ratios 


\section{Tables}

1. CAP analysis assignments for different combinations of data types by production group

\section{Conversion Factors}

International System of Units to U.S. customary units

\begin{tabular}{|c|c|c|}
\hline Multiply & By & To obtain \\
\hline \multicolumn{3}{|c|}{ Length } \\
\hline millimeter (mm) & 0.03937 & inch (in.) \\
\hline micron $(\mu \mathrm{m})$ & 0.00003937 & inch (in.) \\
\hline \multicolumn{3}{|c|}{ Flow rate } \\
\hline microns per second $(\mu \mathrm{m} / \mathrm{s})$ & $3.281 \times 10-6$ & foot per second $(\mathrm{ft} / \mathrm{s})$ \\
\hline \multicolumn{3}{|c|}{ Mass } \\
\hline $\operatorname{gram}(\mathrm{g})$ & 0.03527 & ounce, avoirdupois (oz) \\
\hline
\end{tabular}

\section{Supplemental Information}

All reported elemental data are element-to-calcium ratios in micromole/mole $(\mu \mathrm{mol} / \mathrm{mol})$, except for strontium in millimole $/ \mathrm{mole}(\mathrm{mmol} / \mathrm{mol})$.

\section{Abbreviations}

$\begin{array}{ll}\text { Al } & \text { artificial incubation } \\ \text { ANOVA } & \text { analysis of variance } \\ \text { ASB } & \text { artificial spawning beach } \\ \text { Ba } & \text { barium } \\ \text { Ca } & \text { calcium } \\ \text { CAP } & \text { canonical analysis of principal coordinates } \\ \text { Cu } & \text { copper } \\ \text { EDC } & \text { early developmental check } \\ \text { Fe } & \text { iron } \\ \text { FFC } & \text { first feed check } \\ \text { FL } & \text { fork length } \\ \text { HC } & \text { hatch check } \\ \text { HGMP } & \text { Hatchery Genetic Management Plan } \\ \text { HSRG } & \text { Hatchery Scientific Review Group }\end{array}$




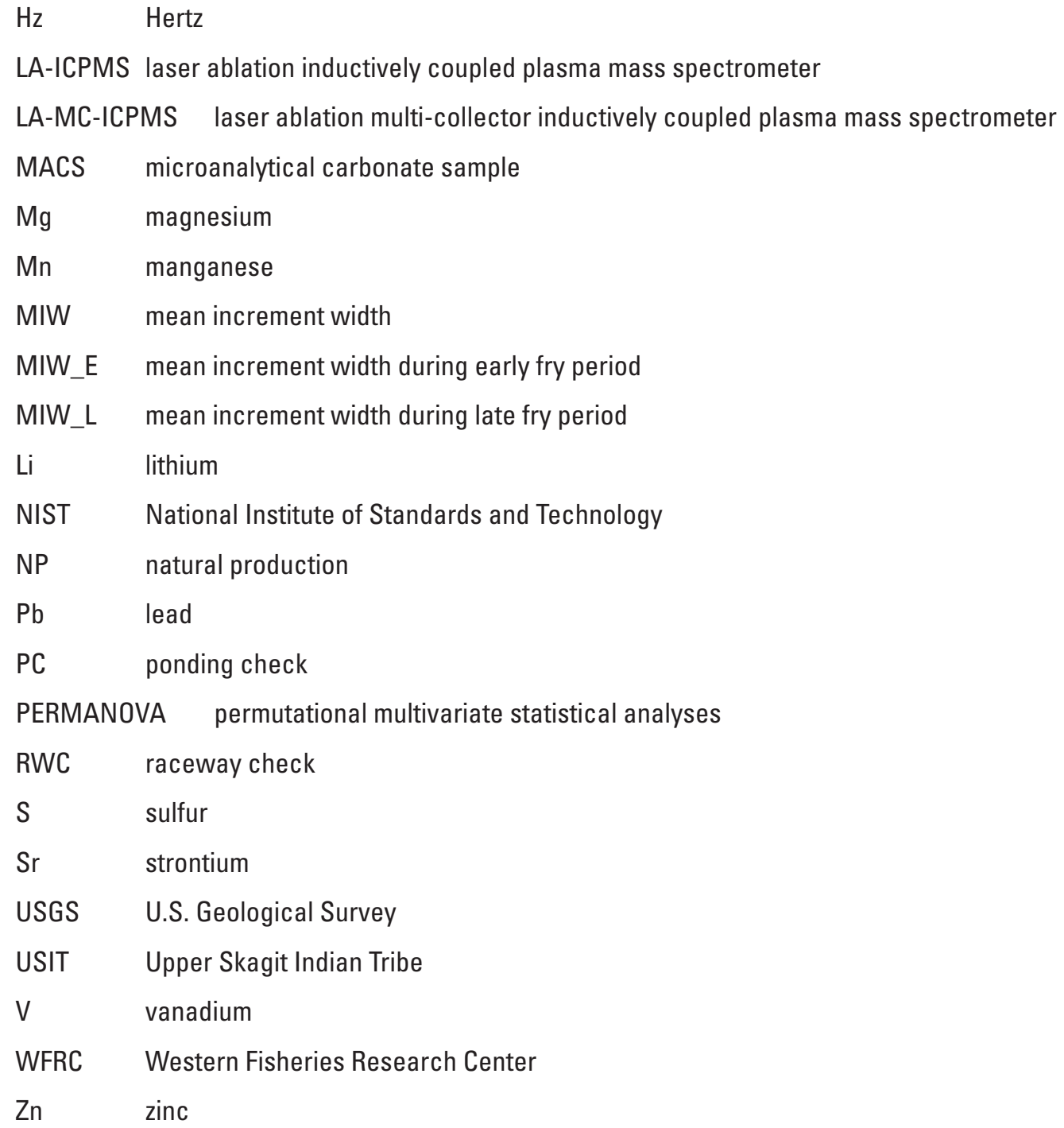





\title{
Investigation of Otolith Microstructure and Composition for Identification of Rearing Strategies and Associated Baker Lake Sockeye Salmon (Oncorhynchus nerka) Smolt Production, Washington, 2016-17
}

\author{
By Kimberly A. Larsen, Lisa A. Wetzel, Karl D. Stenberg, and Angie M. Lind-Null
}

\section{Introduction}

Baker River sockeye salmon (Oncorhynchus nerka) are a recovering Puget Sound stock. The relative contribution of hatchery and natural adults to overall production of smolts and recruits is unknown. The Hatchery Genetic Management Plan (HGMP) for this stock calls for supplemental hatchery production to boost existing natural production. Although the term "natural production" is used throughout this report, the Baker River Watershed's adult and juvenile salmon migratory connectivity to spawning and rearing habitats is blocked by two high head dams, requiring some human intervention. Trap-and-haul facilities enable the upstream and downstream movement of fish around the dams to connect them to the habitat types needed for completion of their lifecycle. Fisheries managers anticipate that both hatchery and natural production will aid in the re-colonization of the Baker Watershed. However, the Hatchery Scientific Review Group (HSRG) has recommended that hatchery production be evaluated so as not to exceed the carrying capacity of Baker Lake. Therefore, the ability to identify three different sockeye production groups (natural production [NP], artificial incubation [AI], and artificial spawning beach [ASB]) within the Baker system is crucial to moving forward with management goals. The examination of otoliths was proposed as a technical tool for improved understanding and management of Baker sockeye rebuilding efforts. Otoliths were chosen as they provide a chronological record on an individual fish basis and have been shown to identify fish origin through both otolith microstructure (Zhang and others, 1995; Barnett-Johnson and others, 2007) and chemistry (Kennedy and others, 2000; Barnett-Johnson and others, 2008). This project evaluates the microstructure, chemical, and isotopic analysis potential of otoliths collected from each of the three production groups within Baker Lake. The data either are not available or have limited availability due to proprietary restrictions. Contact Upper Skagit Indian Tribe (USIT) for more information (Natural Resources Department, 360-854-7100).

\section{Methods}

Sockeye fry were collected in early spring 2016 by USIT at their respective production group sites after the natural fish had emerged and begun migrating to Baker Lake. Samples from the NP group were collected from the Baker River, near the entrance to Baker Lake, on multiple dates (March 4, March 7, and March 16) in order to meet a pre-determined sample size (approximately 50 for each production group), and hatchery samples (AI and ASB) were collected on March 4, 2016 from the Baker River Hatchery raceways and its associated artificial spawning beach. Adult sockeye are transferred to the artificial gravel beach on hatchery grounds adjacent to Baker Lake to spawn naturally, where their eggs incubate and their fry emerge using a shared water source with the hatchery, but with no feeding regime. Samples were placed into 95 percent non-denatured ethyl alcohol for otolith preservation and transferred to the U.S. Geological Survey (USGS), Western Fisheries Research Center in Seattle, Washington on November 17, 2016.

A total of 153 sockeye fry (26-31 mm fork length [FL]) were received from three different production groups: Baker River NP $(n=52)$, Baker River Hatchery AI $(n=52)$, and Baker River Hatchery ASB $(n=49)$. All samples were measured and weighed for preserved FL ( $\mathrm{mm}$ ) and weight (g) and assigned a unique sample number. Otoliths were extracted and cleaned with 95 percent ethyl alcohol to remove any organic tissue and then placed into vials and allowed to dry under a fume hood until further analysis.

Otolith microstructure processing and analysis followed the methods of Stevenson and Campana (1992). Otoliths were mounted in clear epoxy resin and then polished on both sides of the otolith to produce a thin section. Polishing wheels were used with progressively finer polishing cloths and slurries of silicon carbide and aluminum oxide to achieve optimal visual resolution. Twelve total otoliths were either lost or over ground during processing. These 12 samples were supplemented with their complementary right otolith in order to retain sample size. Before supplementing, the potential 
substitutes were measured for verification of equal length to the left otolith to account for any growth differences. Upon initial analysis of microstructure patterning, nine AI yearling samples (124-138 mm FL) from the same brood year as the initial 52 fry AI samples, were obtained upon our request from the tribes and processed to help confirm the presence of a microstructure pattern associated with transfer to hatchery raceways.

Polished otoliths were digitally imaged and analyzed using Image-Pro Premier software version 9.3 (Media Cybernetics, Inc., Rockville, MD, USA). A standardized radial axis was used for analyzing all otoliths: $55 \pm 5$ degrees dorsal to a longitudinal axis which passes through a consistently identified nuclei (Wilson and Larkin, 1982; Volk and others, 1995). Microstructure pattern differences related to production group (NP, AI, and ASB) were initially addressed through visual analysis. Prominent marks, known as checks, can interrupt a pattern sequence and be indicative of early life history events (hatching, emergence, first feed) or hatchery rearing events (ponding, transfer to raceways) (Stevenson and Campana, 1992; Zhang and others, 1995). Checks, along with individual increments were identified. Each increment, assumed to be daily, was counted and measured (increment width in microns $[\mu \mathrm{m}]$ ) inward along the radial axis, from the outer otolith edge to a prominent check early in development. This early developmental check (EDC) was consistent among all production groups and located between the hatch check (HC) and first feed check (FFC). Inward counts to checks were compared to known dates of events associated with the checks, when available.

Due to the inability to quickly observe visual differences in the microstructure pattern between production groups, a subset of at least 30 otoliths from each production source $(\mathrm{NP}=30, \mathrm{AI}=31, \mathrm{ASB}=30$ ) was measured for distances $(\mu \mathrm{m})$ from the core region of the otolith to various life history events (hatching, first feed etc.) and other checks associated with rearing events (ponding, transfer to raceway) (BarnettJohnson and others, 2007; Volkoff and Titus, 2007). The AI yearling samples were visually analyzed and measured to aid in further distinguishing between production groups.

A subset of right otoliths $(n=38)$ from the production groups ( $\mathrm{NP}=13, \mathrm{AI}=13, \mathrm{ASB}=12)$ was used for microchemical analysis. Otoliths were mounted and processed according to the methods of Donohoe and Zimmerman (2010). Once processed, the samples were cleaned in an ultrasonic bath using nanopure water for 1 minute, dried in a laminar flow hood and then taken to Oregon State University's W.M. Keck Collaboratory for Plasma Spectrometry where they were analyzed using a LA-ICPMS (laser ablation inductively coupled plasma mass spectrometer; a Photon Machines G2 laser with a Thermo electron XS2 mass spectrometer). Each sample was analyzed for a standard suite of 13 elements (atomic weights and abbreviations in parentheses): lithium $\left({ }^{7} \mathrm{Li}=\mathrm{Li}\right)$, magnesium $\left({ }^{24} \mathrm{Mg}+{ }^{25} \mathrm{Mg}=\mathrm{Mg}\right)$, sulfur $\left({ }^{33} \mathrm{~S}=\mathrm{S}\right)$, calcium $\left({ }^{43} \mathrm{Ca}\right.$ $=\mathrm{Ca})$, vanadium $\left({ }^{51} \mathrm{~V}=\mathrm{V}\right)$, manganese $\left({ }^{55} \mathrm{Mn}=\mathrm{Mn}\right)$, iron $\left({ }^{56} \mathrm{Fe}=\mathrm{Fe}\right)$, copper $\left({ }^{65} \mathrm{Cu}=\mathrm{Cu}\right)$, zinc $\left({ }^{66} \mathrm{Zn}=\mathrm{Zn}\right)$, strontium $\left({ }^{86} \mathrm{Sr}=\mathrm{Sr}\right)$, barium $\left({ }^{138} \mathrm{Ba}=\mathrm{Ba}\right)$, lead $\left({ }^{208} \mathrm{~Pb}=\mathrm{Pb}\right)$. One radial transect, running from the core to the edge, and 3 edge spots were run per sample. The edge spots were run to ensure that data collected along the transect was beyond any detection of a maternal signal on the otoliths because the samples were sacrificed early in development, not providing much distance on the otolith for analysis beyond any maternal influence. The ICPMS transects were implemented using a $30 \mu \mathrm{m}$ spot size with a pulse rate of $20 \mathrm{~Hz}$ and a scan rate of $5 \mu \mathrm{m} / \mathrm{s}$. Standards (NIST-612 and USGS MACS-3) were run every six samples and used to correct for instrument bias and drift. All data were converted from counts per microsecond to counts per micrometer based on scan speed. Each data point had background levels subtracted, was internally standardized to $\mathrm{Ca}$ (by dividing the element by $\mathrm{Ca}$ ), corrected for bias by multiplying a correction factor (based on NIST-612 measured and reported values) and then converted to molar concentration ratios (Miller and others, 2005).

The same otoliths were then digitally imaged and sent to the University of Utah's Department of Geology and Geophysics ICPMS facility where they were analyzed for Sr isotope ratios $\left({ }^{87} \mathrm{Sr} /{ }^{86} \mathrm{Sr}\right.$ ) using a LA-MC-ICPMS (laser ablation multi-collector inductively coupled plasma mass spectrometer). Due to some unforeseen events during set-up, the number of samples was reduced from 38 to 36 for isotope analysis. A transect of $\sim 150 \mu \mathrm{m}$, perpendicular to the elemental transect laser scar, was run per sample. The laser transect was set up remotely by USGS employees and was run from the otolith core toward either the rostrum or postrostrum, depending on available space with uninterrupted otolith growth (no intrinsic folds or cracks) and followed the otolith edge contour between $150 \mu \mathrm{m}$ from the otolith core and the otolith edge (fig. 1). The LA-MC-ICPMS transects were implemented using a spot size of $50 \mu \mathrm{m}$ with a pulse rate of $10 \mathrm{~Hz}$ and a scan rate of $2 \mu \mathrm{m} / \mathrm{s}$. A marine standard (shell material) was used in calibrating the isotope results (measured at ${ }^{87} \mathrm{Sr}{ }^{86} \mathrm{Sr}=0.70921$ [SD 0.00005]) compared to the global marine value of 0.70918 . The data were adjusted for mass bias using an exponential law associated with radioactive decay and for isobaric interferences as is standard for this type of analysis (Brennan and others, 2015).

One-way analysis of variance (ANOVA) was used to test for significant $(p=0.05)$ differences among production groups in microstructure increment widths (average/otolith), measured distances, and microchemistry concentrations for elements and isotopes. The otolith microstructure data was divided into two otolith regions for testing purposes: early fry development (defined as the region of otolith encompassing from EDC to FFC) and late fry development (defined as the region of otolith encompassing from FFC to otolith edge or transfer to raceways in the case of group AI). The elemental chemistry data was also divided into two otolith target regions for testing based upon peaks and valleys in the output: Region A (defined as the first $50 \mu \mathrm{m}$ of the transect from the otolith core [0-50 $\mu \mathrm{m}]$ ) and Region B (defined as 150-200 $\mu \mathrm{m}$ from the otolith core, corresponding to a consistent region 


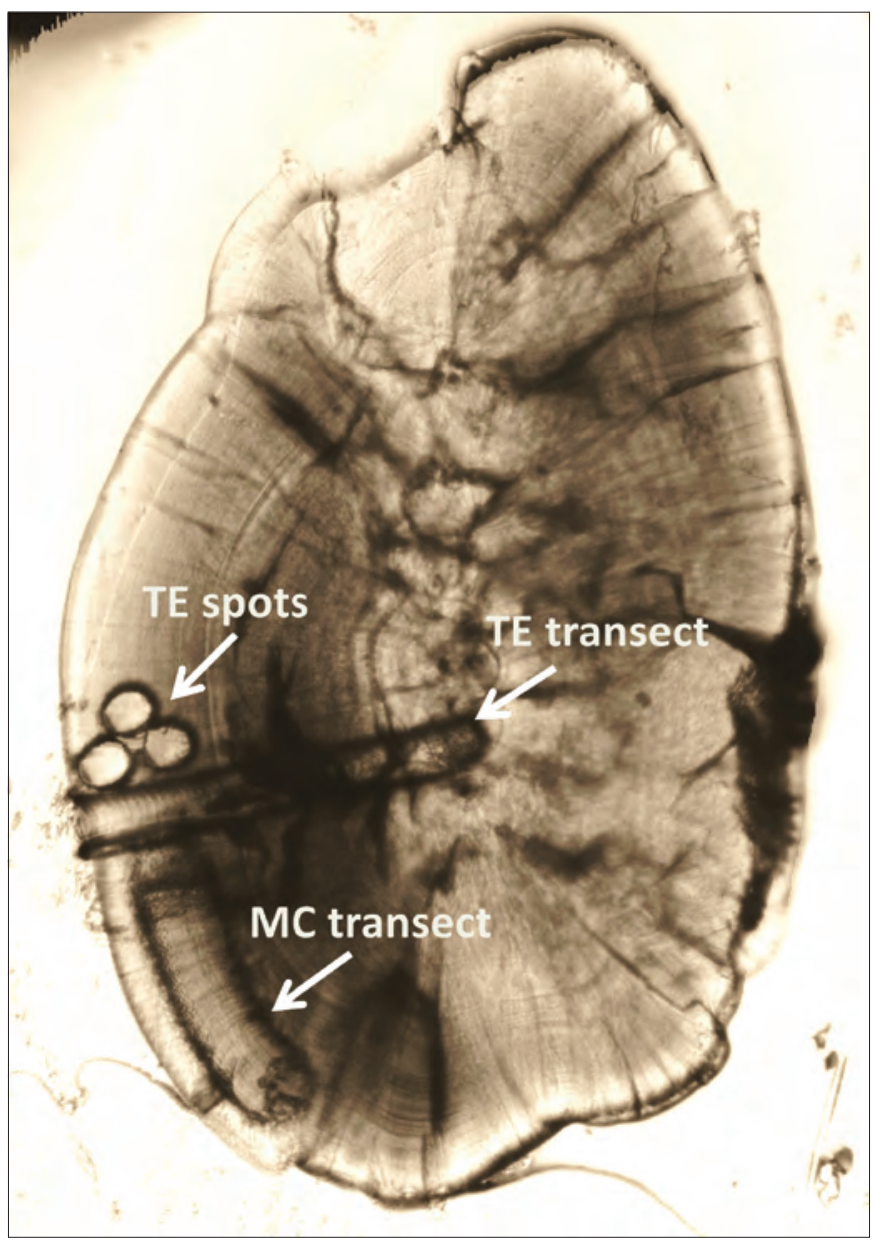

Figure 1. Representative polished otolith sample, depicting the locations of laser scars (trace element transect [TE transect] and multi-collector transect [MC transect]) and spots (trace element spots [TE spots]) after microchemical analysis (Zeiss compound microscope, $7 \times$ magnification).

of post-maternal influence for comparison among production groups). Tukey's tests were used to determine exactly which production groups were different for measurements and elemental and isotopic concentrations. To look at the variation among production groups for all measurements together, a series of permutational multivariate statistical analyses (PERMANOVA) was run using data in which all variables were set to a standard scale (the difference between the value and the mean divided by the standard deviation) and those nonnormally distributed were log-transformed (elements Mn and $\mathrm{Zn}$ only). The resulting, adjusted microstructural and microchemical variables were initially included in a PERMANOVA to verify the existence of differences among production groups and then analyzed using a canonical analysis of principal coordinates (CAP) to quantify the accuracy of classification to production groups (Wells and others, 2003; Barnett-Johnson and others, 2007; Volkoff and Titus, 2007). The number of permutations per analysis was set at 9,999. The number of samples common to all data types was 35 (11 AI, 12 ASB, and $12 \mathrm{NP}$ ). Following this analysis, different data types were progressively removed (in other words, isotope ratios, microstructure) and the CAP analysis re-run to determine the value of each type of data on its own or in combination. R statistical software v3.2.1(R Core Team, 2015) was used for analysis of variance and Primer v7 and PERMANOVA+ statistical software (Anderson and others, 2008) was used for all multivariate analyses.

\section{Results}

Upon initial visual analysis of the microstructure patterning, it was difficult to discern all three production groups. Samples from all production groups had prominent markings in the same regions of the otolith and the increment spacing did not look to vary significantly among production groups, as previously discerned for some salmonids (Zhang and others, 1995; Barnett-Johnson and others, 2007) (figs. 2-4). However, samples from the AI group showed the possibility of a distinct check at the otolith edge, potentially aiding in the identification of that production group. It was assumed to be the beginning of a check associated with transfer to the raceways due to its prominence and proximity to the otolith edge (AI group sacrificed 2 days after transfer to raceways; fig. 4). Unfortunately, one could easily confuse it with an edge effect from lighting due to such close edge proximity. Therefore, yearling samples from the same brood year were obtained and processed to aid in verification of its existence and association with transfer to the raceway. Upon examination of the yearling otoliths, we were able to identify a distinct Raceway Check (RWC) at approximately the same distance from the core and to other checks /life history events as in the corresponding sub-yearling AI group (figs. 4-6).

The ANOVA revealed no significant difference between production groups in microstructure mean increment width (MIW) and distance to HC (fig. 7 and table 1.1). The distances to EDC and FFC were found to be significantly different among production groups (fig. 7). EDC distances were significantly smaller for the NP group than the ASB and AI groups (Tukey's test, $p=0.05$ ). Similarly, there were significant differences among all the production groups in FFC distances (Tukey's test, $p=0.05$ ), with AI being larger than ASB, which was larger than NP.

The elemental laser transects produced expected patterns of variation in the Sr-to-Ca ratios consistent with anadromous fish (high levels of strontium in the core due to maternal marine influence and declining toward the otolith edge; (Rieman and others, 1994; Miller and Kent, 2009) (fig. 8). Based on this information, it was determined that the remaining edge area beyond any maternal influence was wide enough to obtain a consistent average value for the other elements. Therefore, the transect data with more data points was chosen for analyses instead of the spot data with only a few data points. Of the 13 trace elements scanned during LA-ICPMS, 


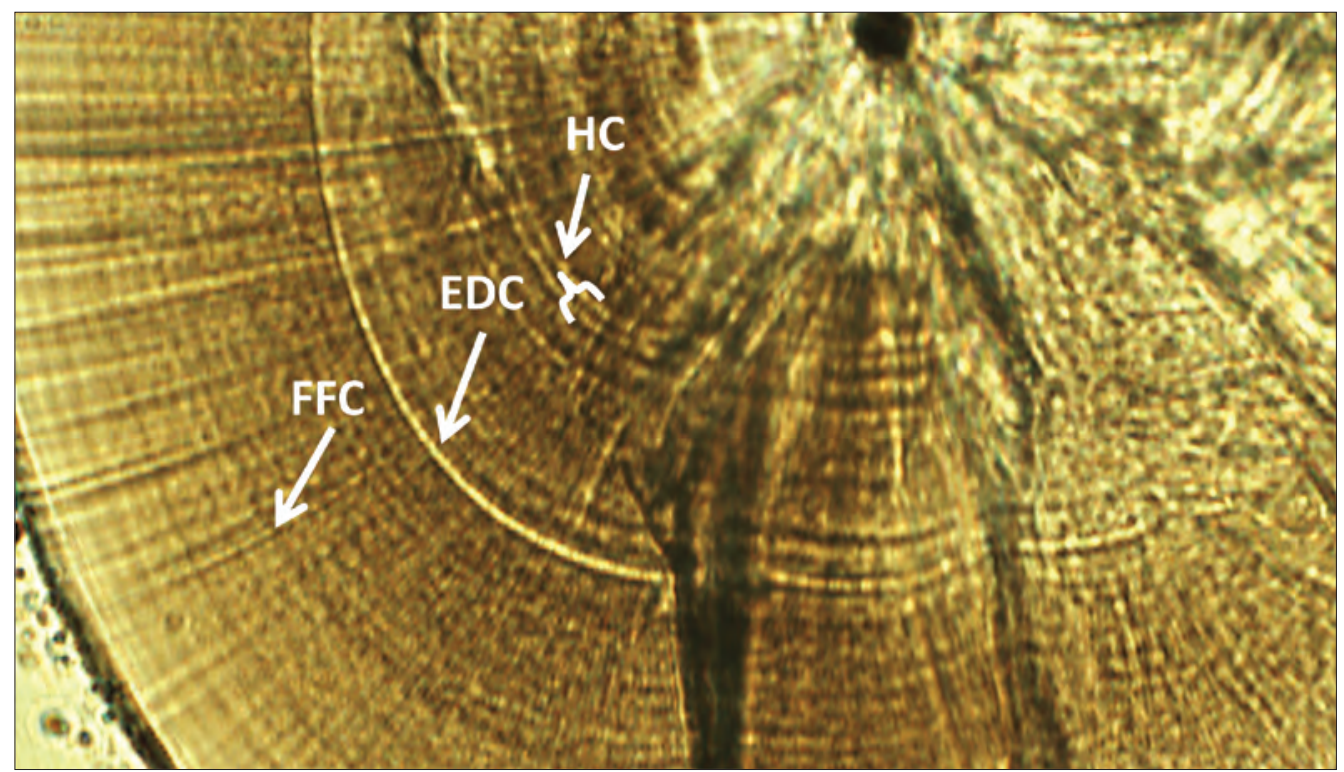

Figure 2. A representative polished sockeye salmon fry otolith from the natural production (NP) group, identifying hatch check (HC), early development check (EDC), and first feed check (FFC) collected from the Baker River, Washington, March 2016 (Zeiss compound microscope, $28 \times$ magnification).

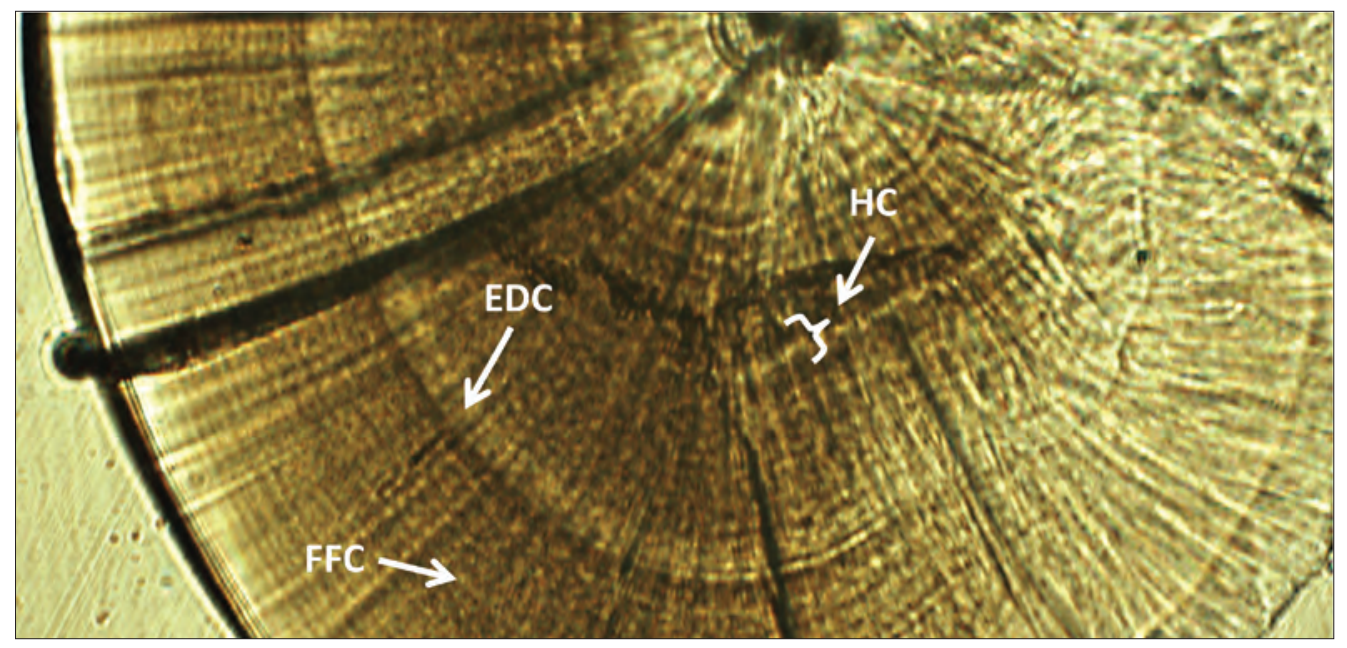

Figure 3. A representative polished sockeye salmon fry otolith from the artificial spawning beach (ASB) group, identifying hatch check (HC), early development check (EDC), and first feed check (FFC) collected from the Artificial Spawning Beach of the Baker River Hatchery, Washington, March 2016 (Zeiss compound microscope, $28 \times$ magnification). 


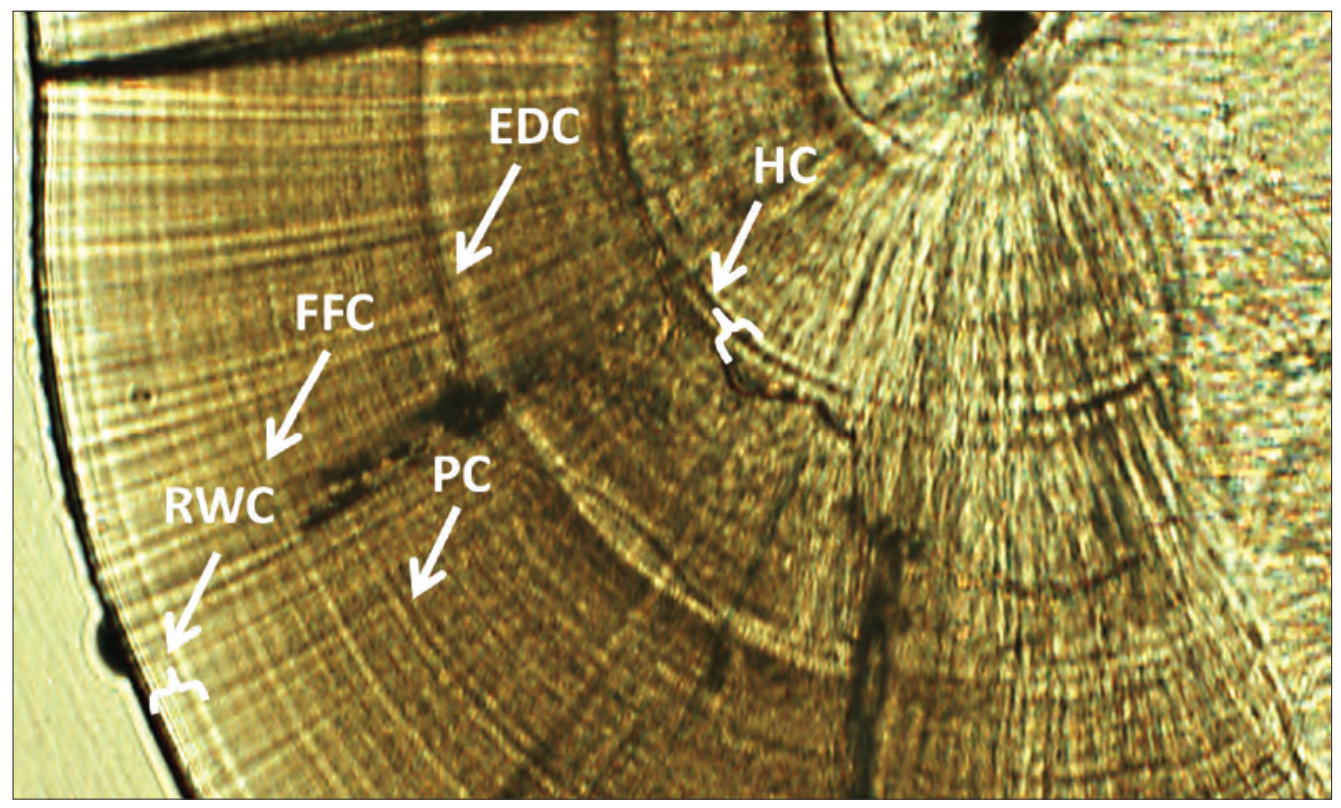

Figure 4. A representative polished sockeye salmon fry otolith from the artificial incubation (Al) group, identifying the hatch check $(\mathrm{HC})$, early development check (EDC), ponding check (PC), first feed check (FFC), and the beginnings of a raceway check (RWC) collected from the Baker River Hatchery, Washington, March 2016 (Zeiss compound microscope, $28 \times$ magnification).

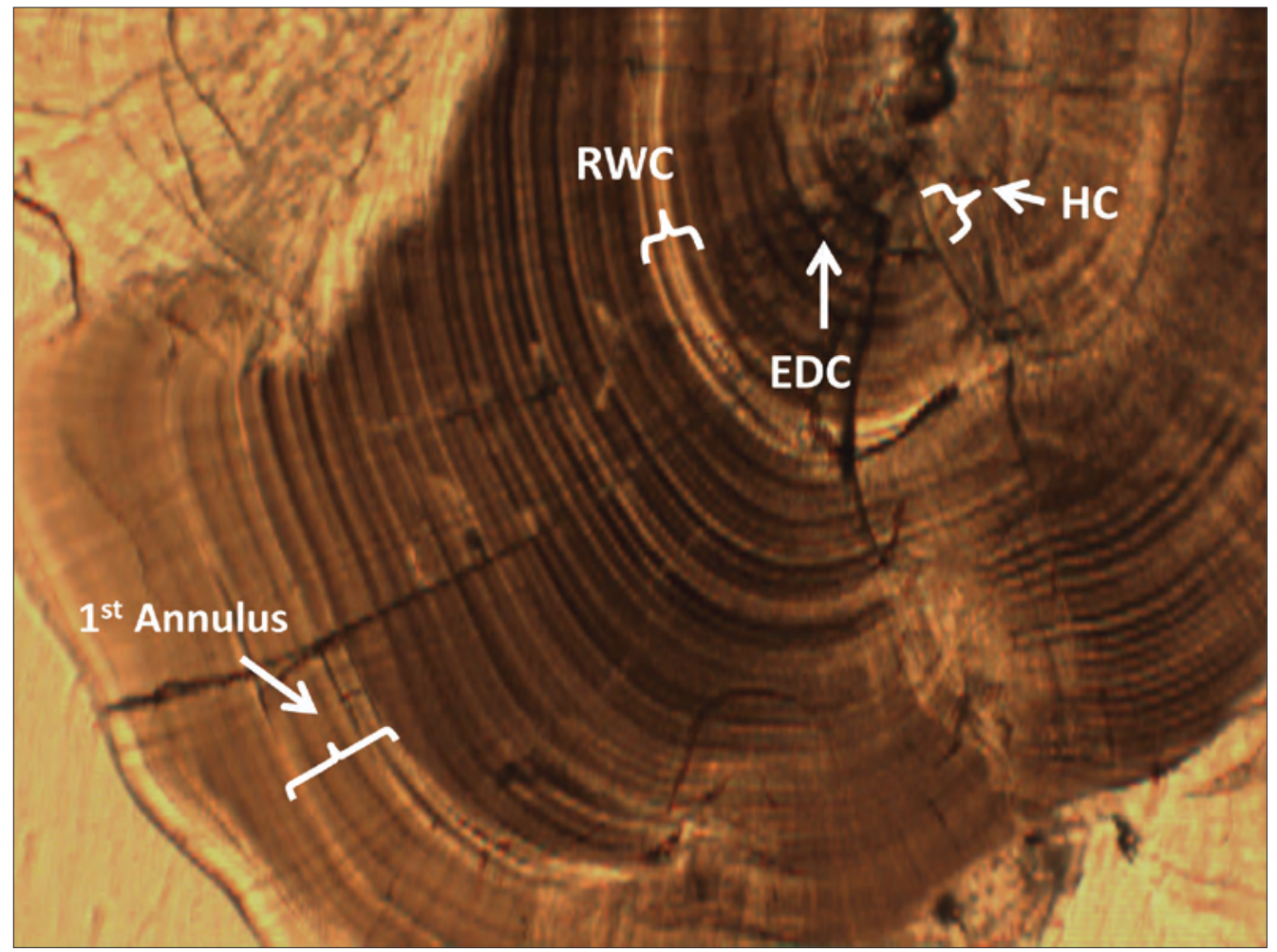

Figure 5. A representative polished yearling sockeye salmon otolith from the artificial incubation (Al) group, displaying the entire otolith from core to edge, identifying the hatch check $(\mathrm{HC})$, early development check (EDC), complete raceway check (RWC), and 1st annulus (time at age-1) collected from the Baker River Hatchery, Washington, 2017 (Zeiss compound microscope, $7 \times$ magnification). 


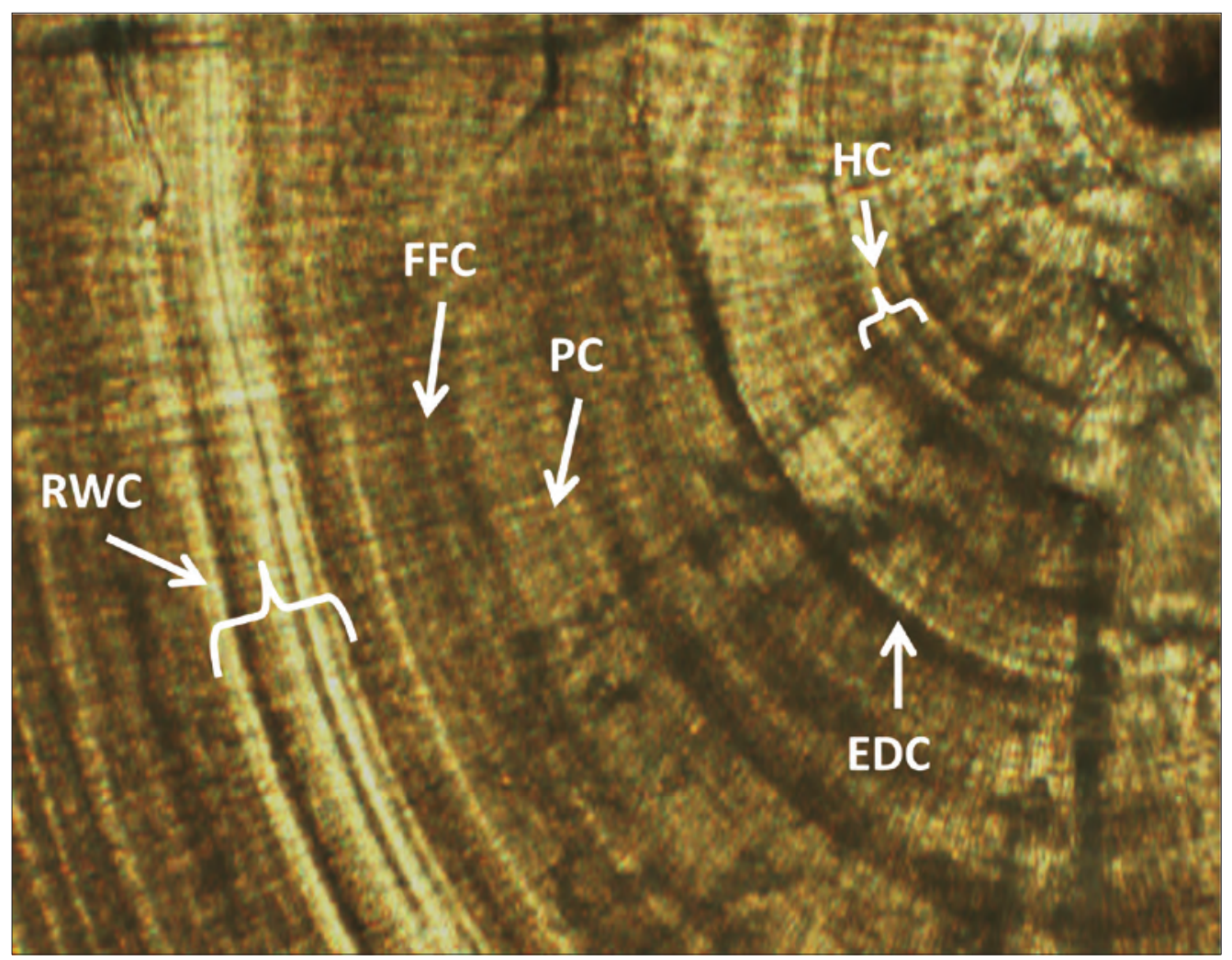

Figure 6. The same representative polished yearling sockeye salmon otolith, identifying the hatch check (HC), early development check (EDC), ponding check (PC), first feed check (FFC), and the complete raceway check (RWC) collected from the Baker River Hatchery, Washington in 2017 (Zeiss compound microscope, $28 \times$ magnification). 


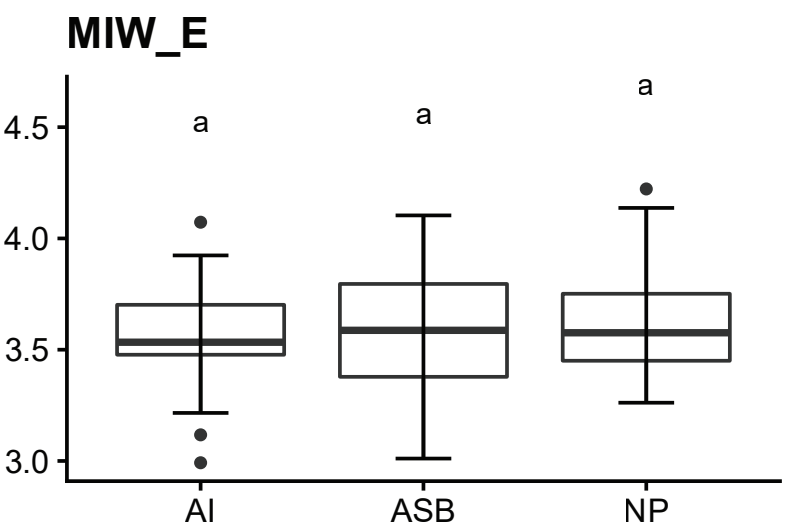

\section{MIW_L}

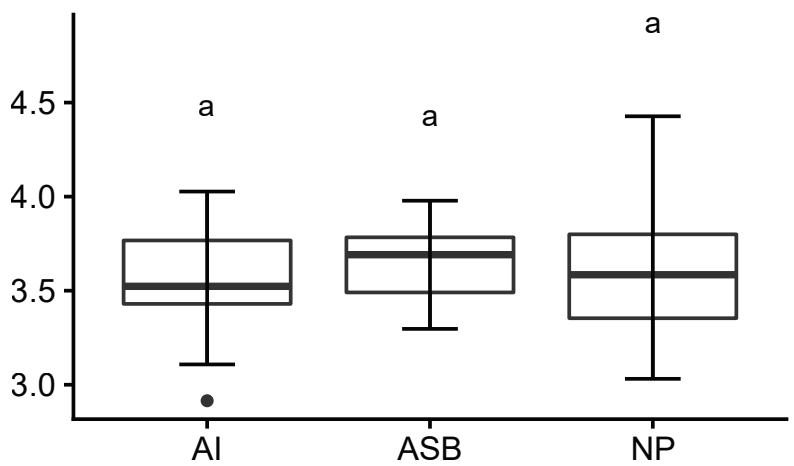

HC

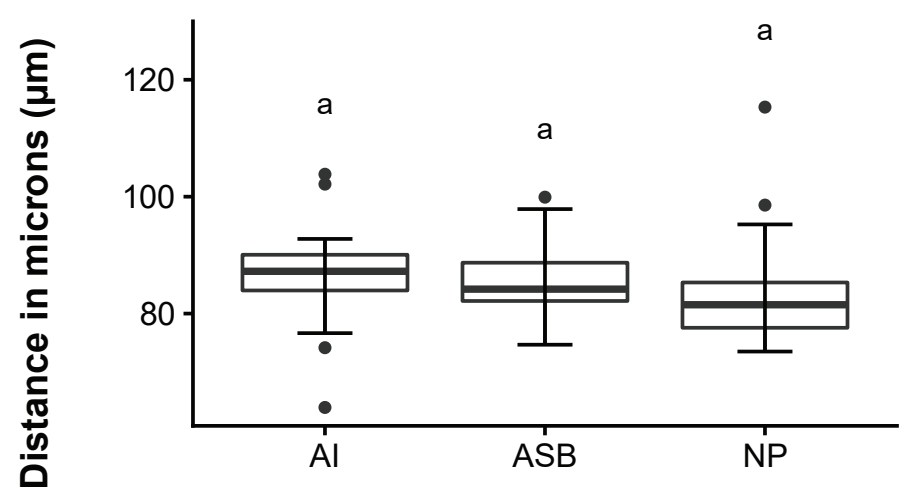

EDC

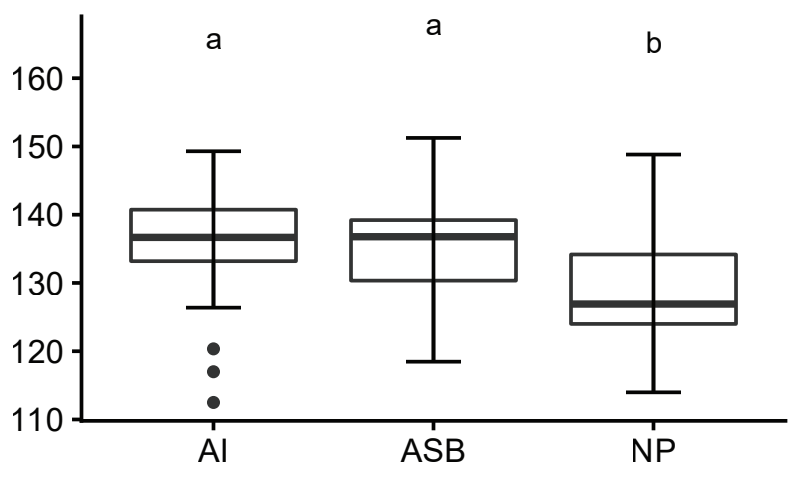

FFC

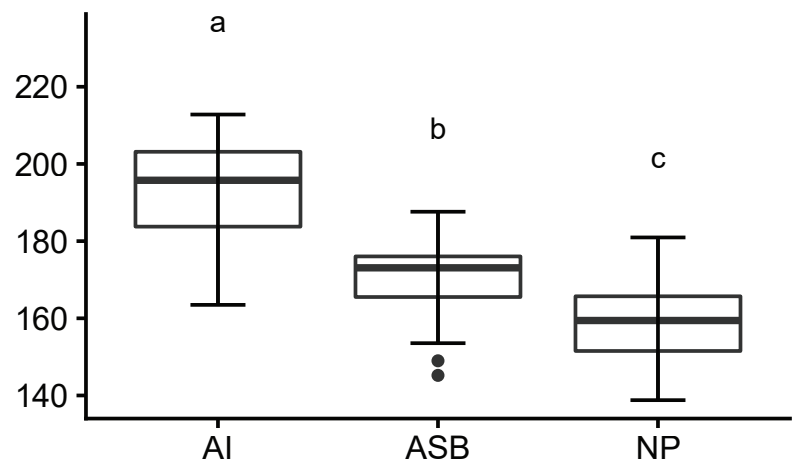

Production groups

Figure 7. Microstructural features (mean increment width in microns [ $\mu \mathrm{m}]$ during early fry period, MIW_E; mean increment

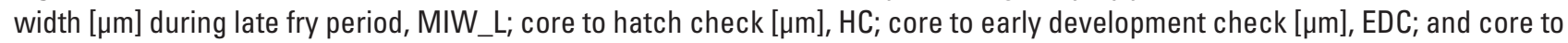
first feed check [ $\mu \mathrm{m}], \mathrm{FFC}$ ) analyzed by production group (artificial incubation [ $n=31]$, Al; artificial spawning beach [ $n=30]$, ASB; natural production [ $n=30]$, NP). Different letters above the whiskers of the production groups indicate significant differences among production groups, $p=0.05$. 


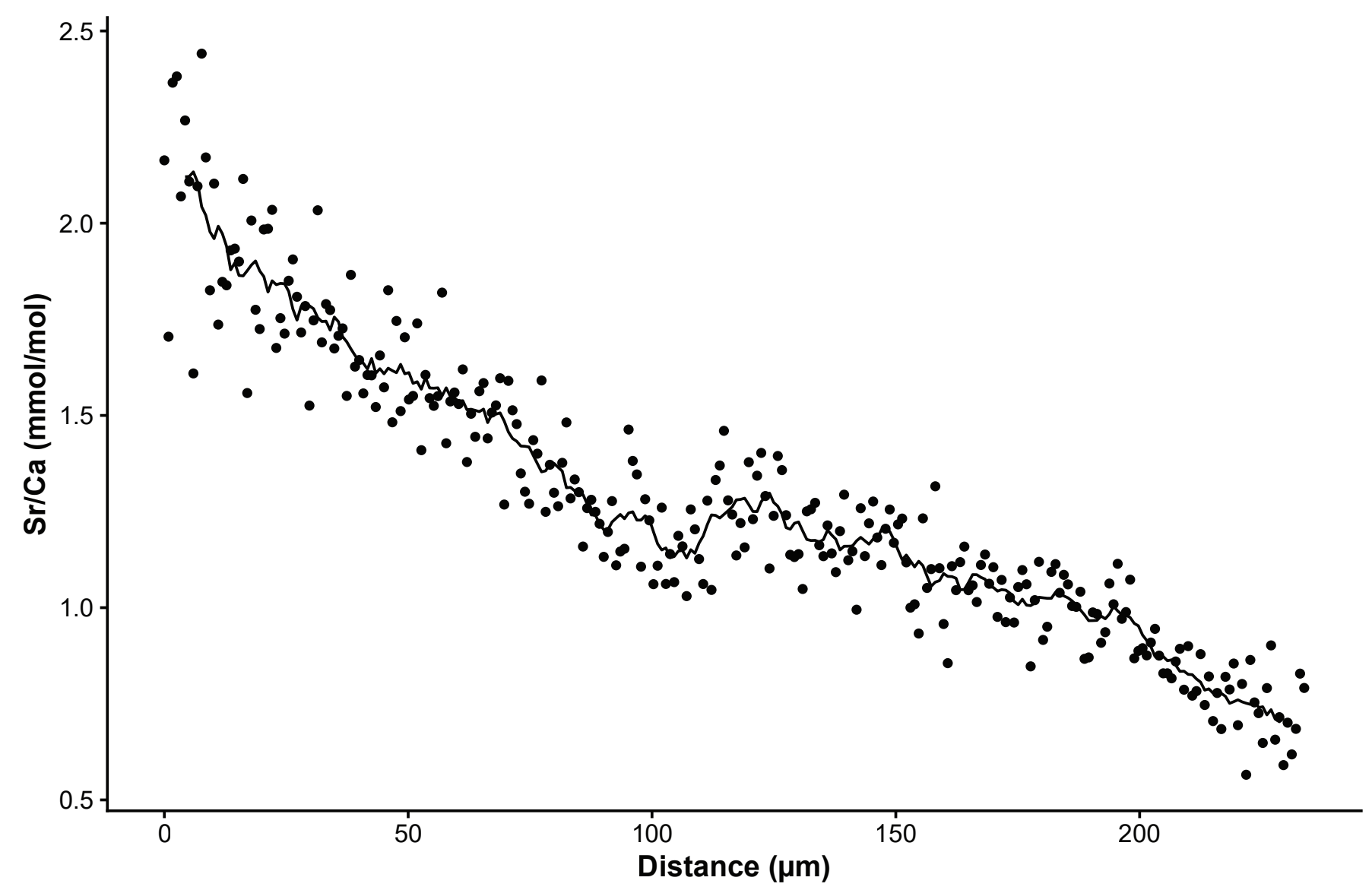

Figure 8. A typical microchemistry transect depicting (1) the decline in strontium-to-calcium ratios (millimole/mole [mmol/mol]) from the core (generally 0-20 microns $[\mu \mathrm{m}]$ ) to the edge associated with high strontium levels in the maternal marine environment during egg formation and (2) the low freshwater strontium levels during subsequent egg-to-fish development. The black line indicates the running mean $(n=10)$. 
only six showed patterns of variation beyond the base level otolith values for a given element. Therefore, those six elements were the elements of choice proceeding forward with analyses $\left({ }^{24+25} \mathrm{Mg} ;{ }^{43} \mathrm{Ca} ;{ }^{55} \mathrm{Mn} ;{ }^{66} \mathrm{Zn} ;{ }^{86} \mathrm{Sr} ;{ }^{138} \mathrm{Ba}\right)$; magnesium 24 and 25 were combined for the analysis. After calculating the corrected values, converting to molar ratios (element-tocalcium) and $\log$ transforming the $\mathrm{Mn} / \mathrm{Ca}$ and $\mathrm{Zn} / \mathrm{Ca}$ data to improve normality, ANOVA revealed significant differences occurring among production groups in the composition of $\mathrm{Mg}$, $\log (\mathrm{Mn}), \log (\mathrm{Zn})$ and $\mathrm{Ba}$ in otolith Region A and the composition of $\mathrm{Sr}$ and $\mathrm{Ba}$ in otolith Region B (fig. 9 and table 1.1). Tukey's tests in Region A resulted in group ASB being significantly different from the other two production groups in the composition of $\mathrm{Mg}, \log (\mathrm{Mn})$ and $\log (\mathrm{Zn})$, and group NP being significantly different from both artificial production groups in the composition of Ba. Furthermore, the NP group was significantly different from the artificial production groups in the composition of $\mathrm{Sr}$ and $\mathrm{Ba}$ in Region $\mathrm{B}$.

Strontium isotope ratios showed a significant difference among production groups using ANOVA, with Tukey's test revealing the NP group to be significantly different from the two artificial production groups (AI and ASB) (fig. 10).

Multivariate analyses were used to test for differences among production groups. PERMANOVA revealed significant differences among production groups overall and among all production group pairings for all data type combinations. Microstructure data alone could not detect a difference between the artificial production groups (see table 1.2).

Using the production group information corresponding to each sample and removing one at a time iteratively (leave-oneout cross validation), CAP was able to correctly assign 88.57 percent of the samples (table 1). Using just microstructure and trace element data, CAP showed the same overall assignment accuracy (88.57 percent) with production group assignments being slightly different. Using microstructure only, CAP classification rate was greatly reduced, with only 77.14 percent overall being assigned correctly. However, using trace elements only, CAP classified samples correctly 88.57 percent of the time, including accurately assigning 100 percent of the natural production fish.

To visualize production group separation and determine which trace elements were contributing the most to sample segregation, the CAP results were graphed in an ordination plot (fig. 11). The vectors that radiate outward from the center of the data indicate their importance based on length and direction. The trace elements contributing to production group segregation include: $\mathrm{MgA}, \log (\mathrm{MnA}), \mathrm{SrB}, \log (\mathrm{ZnA})$, $\log (\mathrm{ZnB}), \mathrm{BaA}$, and $\mathrm{BaB}$. The figure illustrates the clear separation of NP and AI groups, mainly driven by $\mathrm{SrB}, \mathrm{BaA}$ and $\mathrm{BaB}$. An area of overlap exists between the AI and ASB groups, with the separation occurring mainly due to $\mathrm{MgA}, \log$ $(\mathrm{MnA})$ and $\log (\mathrm{ZnA})$. 


\section{Region A}

\section{$\mathrm{Mg} / \mathrm{Ca}$}

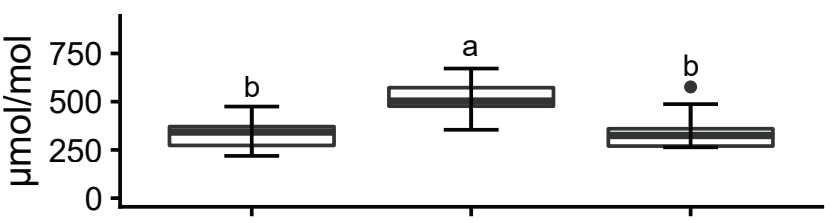

$\log (\mathrm{Mn} / \mathrm{Ca})$

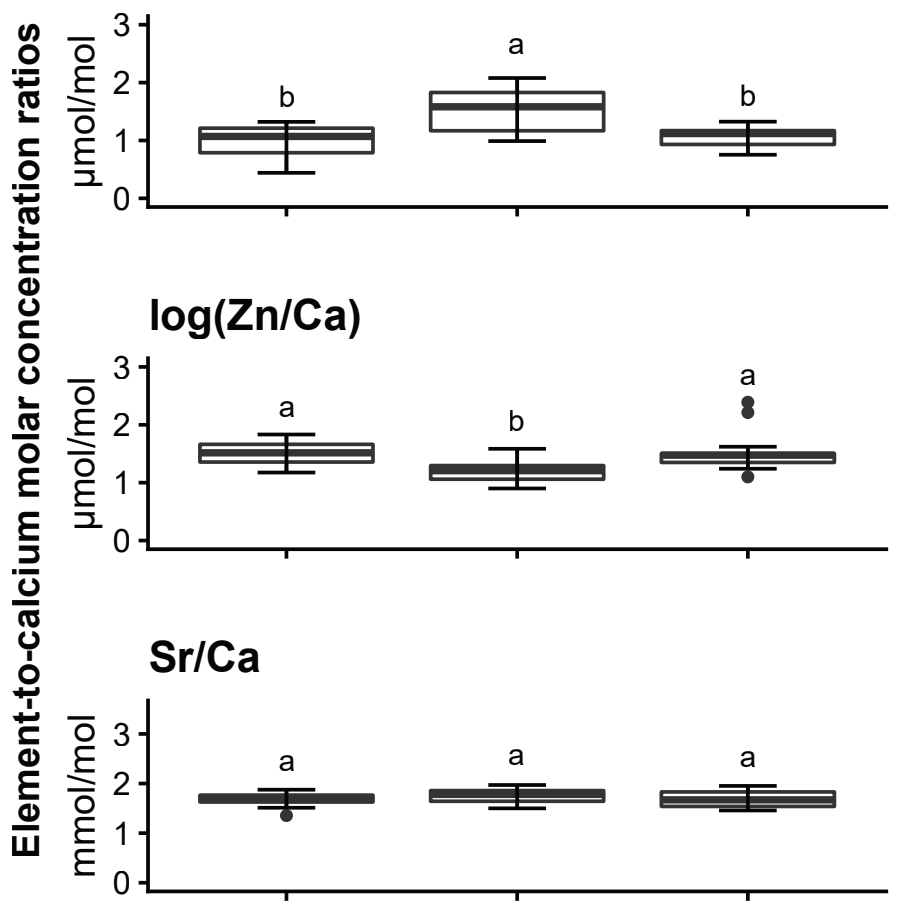

$\mathrm{Ba} / \mathrm{Ca}$

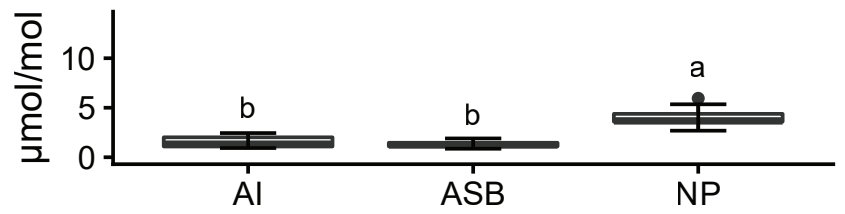

\section{Region B}

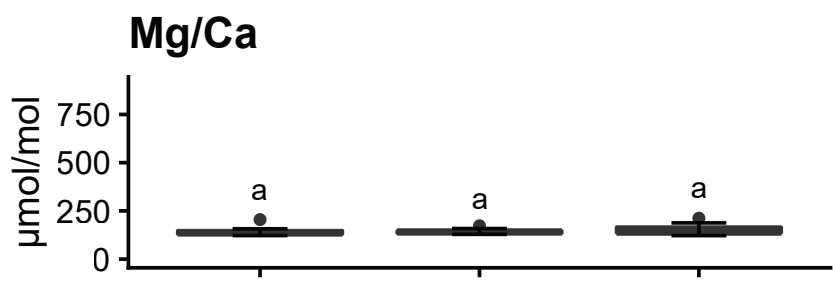

\section{$\log (\mathrm{Mn} / \mathrm{Ca})$}

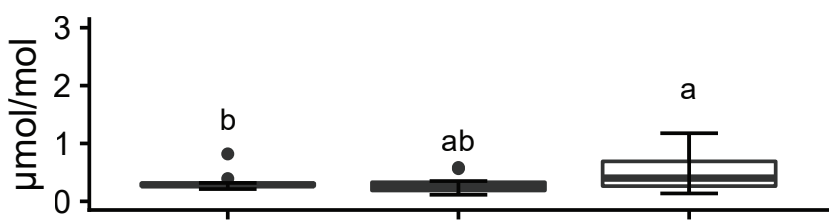

$\log (\mathrm{Zn} / \mathrm{Ca})$

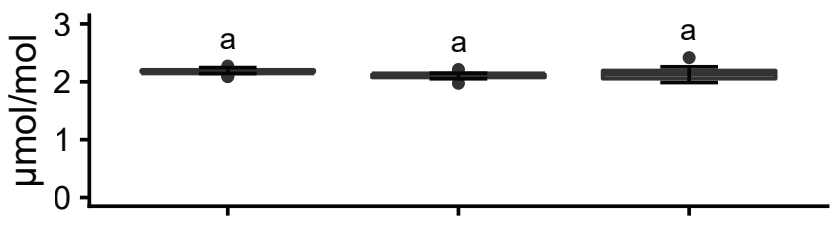

$\mathrm{Sr} / \mathrm{Ca}$

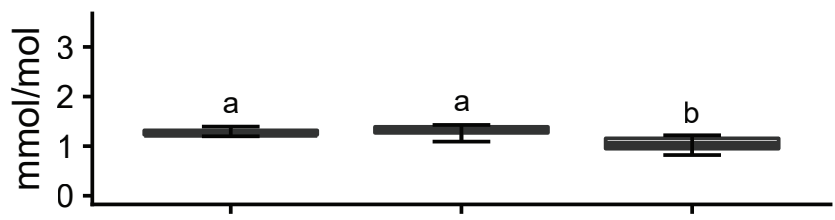

$\mathrm{Ba} / \mathrm{Ca}$

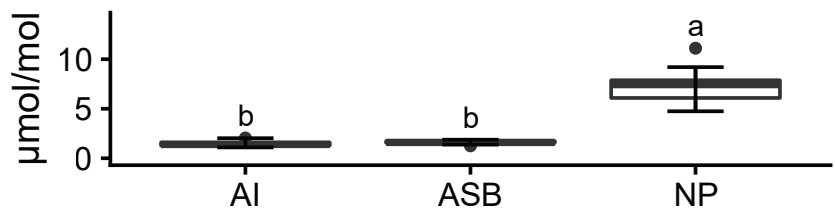

Production groups

Figure 9. Trace element molar concentration ratios (element-to-calcium) for each production group (artificial incubation [ $n=13]$, Al; artificial spawning beach [ $n=12]$, ASB; natural production [ $n=13], N P)$ within Region A ( $0-50$ microns [ $\mu \mathrm{m}]$ from the core) and Region B (150-200 $\mu \mathrm{m}$ from the core). Barium-to-calcium ratios (micromole/mole $[\mu \mathrm{mol} / \mathrm{mol}])$, Ba; magnesium-to-calcium ratios $(\mu \mathrm{mol} / \mathrm{mol}), \mathrm{Mg}$; the logarithm of manganese-to calcium ratios $(\mu \mathrm{mol} / \mathrm{mol}), \log (\mathrm{Mn})$; strontium-to-calcium ratios (millimole/mole $[\mathrm{mmol} / \mathrm{mol}])$, Sr; the logarithm of zinc-to-calcium ratios ( $\mu \mathrm{mol} / \mathrm{mol}), \log (\mathrm{Zn})$. Different letters above the whiskers of the production groups indicate significant differences among production groups, $p=0.05$. 


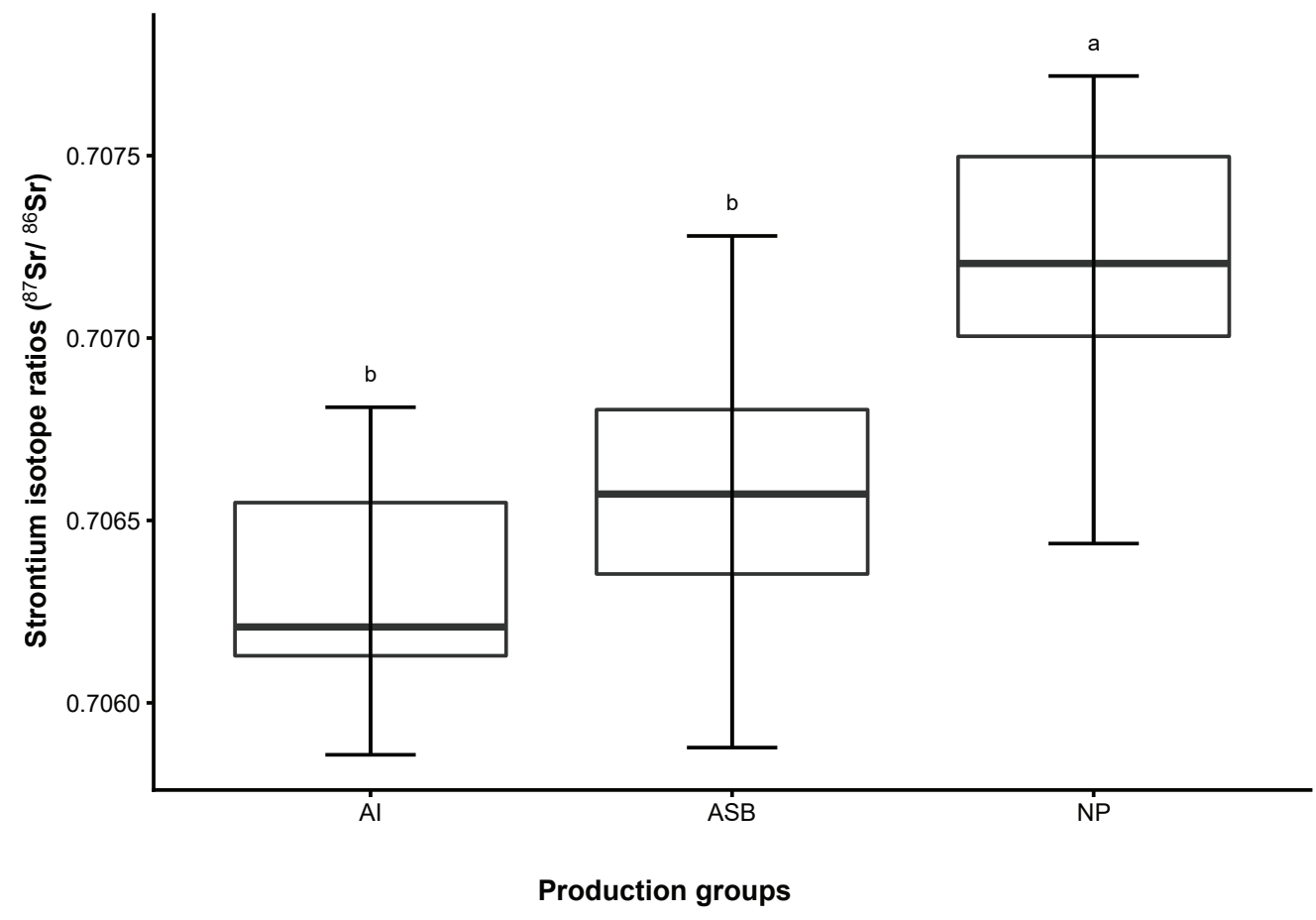

Figure 10. Strontium isotope ratios $\left({ }^{87} \mathrm{Sr} /{ }^{86} \mathrm{Sr}>150\right.$ microns $[\mu \mathrm{m}]$ from the core) for each production group (artificial incubation [ $n=11]$, Al; artificial spawning beach [ $n=13]$, ASB; natural production $[n=12], N P)$. Different letters above the whiskers of the production groups indicate significant differences among production groups, $p=0.05$.

Table 1. CAP analysis assignments for different combinations of data types by production group.

[MS, microstructure; TE, trace elements; Sr-Iso, strontium isotopes; AI, artificial incubation; ASB, artificial spawning beach; NP, natural production]

\begin{tabular}{|c|c|c|c|c|c|c|c|}
\hline Data types & Group & Al & ASB & NP & $\mathrm{n}$ & Percent correct & Percent overall \\
\hline MS, TE, & AI & 10 & 1 & 0 & 11 & 90.91 & 88.57 \\
\hline \multirow[t]{2}{*}{ Sr-Iso } & ASB & 2 & 10 & 0 & 12 & 83.33 & \\
\hline & NP & 1 & 0 & 11 & 12 & 91.67 & \\
\hline \multirow[t]{3}{*}{ MS, TE } & AI & 10 & 1 & 0 & 11 & 90.91 & 88.57 \\
\hline & ASB & 3 & 9 & 0 & 12 & 75.00 & \\
\hline & NP & 0 & 0 & 12 & 12 & 100.00 & \\
\hline \multirow[t]{3}{*}{ MS } & AI & 8 & 2 & 1 & 11 & 72.73 & 74.14 \\
\hline & ASB & 2 & 9 & 1 & 12 & 75.00 & \\
\hline & NP & 0 & 2 & 10 & 12 & 83.33 & \\
\hline \multirow[t]{3}{*}{ TE } & AI & 9 & 2 & 0 & 11 & 81.82 & 88.57 \\
\hline & ASB & 2 & 10 & 0 & 12 & 83.33 & \\
\hline & NP & 0 & 0 & 12 & 12 & 100.00 & \\
\hline
\end{tabular}




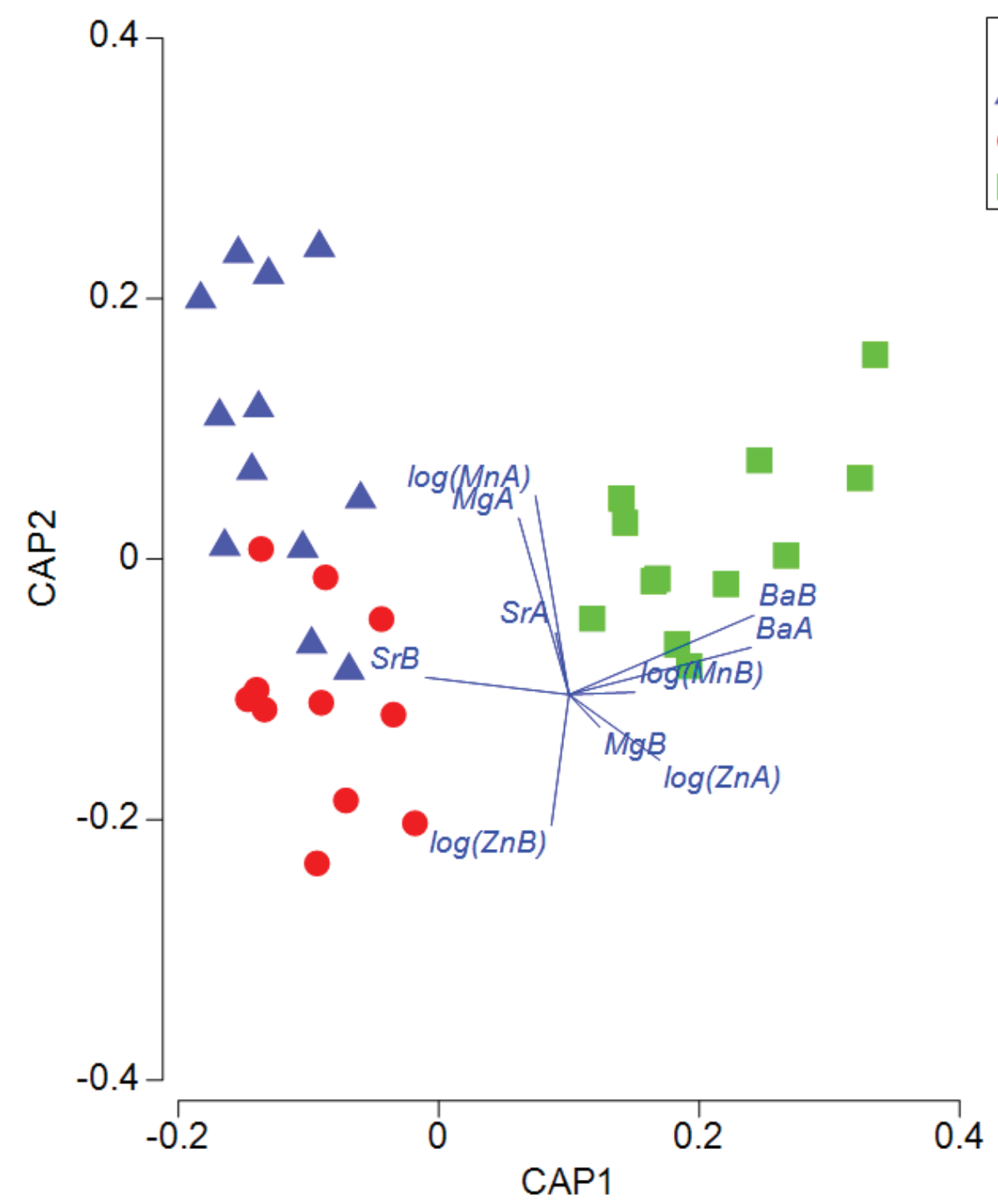

Figure 11. Canonical Analysis of Principal coordinates (CAP) ordination plot showing the separation of production groups (artificial incubation [AI], red circles; artificial spawning beach [ASB], blue triangles; natural production [NP], green squares) by trace elements in molar concentration ratios. Barium-to-calcium ratios in micromole/mole ( $\mu \mathrm{mol} / \mathrm{mol}), \mathrm{Ba}$; magnesium-to-calcium ratios $(\mu \mathrm{mol} / \mathrm{mol})$, $\mathrm{Mg}$; the logarithm of manganese-to calcium ratios ( $\mu \mathrm{mol} / \mathrm{mol}), \log (\mathrm{Mn})$; strontium-to-calcium ratios in millimole $/ \mathrm{mole}(\mathrm{mmol} / \mathrm{mol})$, Sr; the logarithm of zinc-to-calcium ratios $(\mu \mathrm{mol} / \mathrm{mol}), \log (\mathrm{Zn})$. Otolith region 0-50 microns $(\mu \mathrm{m})$ from the core, $A$; otolith region 150-200 $\mu \mathrm{m}$ from the core, B. Radiating lines illustrate the importance to separation by direction and length. 


\section{Conclusions}

The goal of this pilot project was to determine the feasibility of assigning sockeye to their production source based on otolith analysis. A variety of methods were employed and compared for accuracy of group assignment. The maximum overall accuracy capable of attainment was 88.57 percent, however complete confidence (100 percent) in the separation of natural production (NP) from artificial production (AI and ASB combined) was reached through the analysis of trace elements alone. Some segregation of the two artificial production groups was reached by analyzing the trace elements magnesium $(\mathrm{Mg})$, manganese $\log (\mathrm{Mn})$ and zinc $\log (\mathrm{Zn})$, resulting in roughly an 82 (AI) and 83 (ASB) percent confidence in artificial production group assignment. This confidence in assignment for the artificial production groups was aided by a two-step process of combining trace elements with microstructure. The Sr isotope ratios supported the trace element findings but did not help to boost the overall level of confidence in the separation of production groups. Based upon the results from this preliminary investigation, one could choose a statistically sound, efficient, and cost-effective use of otoliths as a tool for discriminating between the sockeye production groups of the Baker Lake system.

The recommendation from this study is to start with trace element analysis of the otoliths: $\mathrm{Ba}, \mathrm{Mg}, \mathrm{Mn}, \mathrm{Zn}$ and $\mathrm{Sr}$. This analysis would provide 100 percent separation between natural and artificial production and roughly an 82 and 83 percent confidence in assignment to AI and ASB groups, respectively and may be enough precision to satisfy management goals. However, to further aid in discriminating the artificial production groups (AI from ASB) and boost confidence in assignment (with minimal additional cost), those artificial production samples with questionable assignment (samples within the area of overlap in fig. 11) could be processed further to analyze their microstructure for the presence of a raceway check (RWC), indicating artificial incubation (AI). Initially, the samples in question may be processed quickly for the presence of an obvious raceway check (RWC), and if not obvious, processed further to confirm presence of the check. In this way, processing costs for microstructure analysis could potentially be minimized. Ideally, before this strategy would be implemented, one should examine year to year variation in trace elements and the raceway check for presence and clarity. Samples should be representative of each population by periodically sampling from yolk absorption through emigration for the ASB and NP groups and at least 14 days past transfer to the raceways for the AI production group. The model would then be strengthened through additional data points, thereby identifying regions of separation and overlap. Once established, future samples of unknown origin could be assigned to production groups with a high level of certainty. Assuming that the analysis of adult otoliths provides similar discrimination levels to fry otoliths (Gillanders, 2002; Miller and others, 2011; Jones and others, 2014), this reliable sorting method could assess the relative survival rates of each production group in a representative sub-sample of hatchery spawners, which are currently a mix of all production groups.

\section{References Cited}

Anderson, M.J., Gorley, R.N., and Clarke, K.R., 2008, PERMANOVA+ for PRIMER - Guide to Software and Statistical Methods: Plymouth, UK, PRIMER-E, p. 214, accessed September 29, 2017, at https://www.primer-e.com.

Barnett-Johnson, R., Grimes, C.B., Royer, C.F., and Donohoe, C.J., 2007, Identifying the contribution of wild and hatchery Chinook salmon (Oncorhynchus tshawytscha) to the ocean fishery using otolith microstructure as natural tags: Canadian Journal of Fisheries and Aquatic Sciences, v. 64, no. 12, p. 1683-1692. [Also available at https://doi.org/ 10.1139/f07-129.].

Barnett-Johnson, R., Pearson, T.E., Ramos, F.C., Grimes, C.B., and MacFarlane, R.B., 2008, Tracking natal origins of salmon using isotopes, otoliths, and landscape geology: Limnology and Oceanography, v. 53, no. 4, p. 1633-1642. [Also available at https://doi.org/10.4319/ lo.2008.53.4.1633.].

Brennan, S.R., Fernandez, D.P., Zimmerman, C.E., Cerling, T.E., Brown, R.J., and Wooller, M.J., 2015, Strontium isotopes in otoliths of a non-migratory fish (slimy sculpin)-Implications for provenance studies: Geochimica et Cosmochimica Acta, v. 149, p. 32-45. [Also available at https://doi.org/10.1016/j.gca.2014.10.032.].

Donohoe, C.J., and Zimmerman, C.E., 2010, A method of mounting multiple otoliths for beam-based microchemical analyses: Environmental Biology of Fishes, v. 89, no. 3-4, p. 473-477. [Also available at https://doi.org/10.1007/ s10641-010-9680-3.].

Gillanders, B., 2002, Connectivity between juvenile and adult fish populations-Do adults remain near their recruitment estuaries?: Marine Ecology Progress Series, v. 240, p. 215-223. [Also available at https://doi.org/10.3354/ meps240215.].

Jones, K.K., Cornwell, T.J., Bottom, D.L., Campbell, L.A., and Stein, S., 2014, The contribution of estuary-resident life histories to the return of adult Oncorhynchus kisutch: Journal of Fish Biology, v. 85, no. 1, p. 52-80. [Also available at https://doi.org/10.1111/jfb.12380.]. 
Kennedy, B.P., Blum, J.D., Folt, C.L., and Nislow, K.H., 2000 , Using natural strontium isotopic signatures as fish markers-Methodology and application: Canadian Journal of Fisheries and Aquatic Sciences, v. 57, no. 11, p. 2280-2292. [Also available at https://doi.org/10.1139/ f00-206.].

Miller, J.A., Banks, M.A., Gomez-Uchida, D., and Shanks, A.L., 2005, A comparison of population structure in black rockfish (Sebastes melanops) as determined with otolith microchemistry and microsatellite DNA: Canadian Journal of Fisheries and Aquatic Sciences, v. 62, no. 10, p. 2189-2198. [Also available at https://doi.org/10.1139/ f05-133.].

Miller, J.A., and Kent, A.J.R., 2009, The determination of maternal run time in juvenile Chinook salmon (Oncorhynchus tshawytscha) based on $\mathrm{Sr} / \mathrm{Ca}$ and ${ }^{87} \mathrm{Sr} /{ }^{86} \mathrm{Sr}$ within otolith cores: Fisheries Research, v. 95, no. 2-3, p. 373-378. [Also available at https://doi.org/10.1016/j .fishres.2008.09.030.].

Miller, J.A., Butler, V.L., Simentstad, C.A., Backus, D.H., and Kent, A.J.R., 2011, Life history variation in upper Columbia River Chinook salmon (Oncorhynchus tshawytscha) - A comparison using modern and $\sim 500$-year-old archaeological otoliths: Canadian Journal of Fisheries and Aquatic Sciences, v. 68, no. 4, p. 603-617. [Also available at https://doi.org/10.1139/f2011-002.].

R Core Team, 2015. R-A language and environment for statistical computing: R Foundation for Statistical Computing, Vienna, Austria, accessed September 28, 2017, at https://www.R-project.org/.

Rieman, B.E., Myers, D.L., and Nielsen, R.L., 1994, Use of Otolith Microchemistry to discriminate Oncorhynchus nerka of resident and anadromous origin: Canadian Journal of Fisheries and Aquatic Sciences, v. 51, no. 1, p. 68-77. [Also available at https://doi.org/10.1139/f94-009.].
Stevenson, D.K., and Campana, S.E., 1992, Otolith microstructure examination and analysis: Canadian Special Publication of Fisheries and Aquatic Sciences, v. 117, p. 1-126. [Also available at https://doi.org/10.13140/ RG.2.2.22258.61127.].

Volk, E.C., Mortensen, D.G., and Wertheimer, A.C., 1995, Nondaily otolith increments and seasonal changes in growth of a pink salmon (Oncorhynchus gorbuscha) population in Auke Bay, Alaska, in Secor, D.H., Dean, J.M., and Campana, S.E., eds., Recent developments in fish otolith research: Columbia, South Carolina, University of South Carolina Press, p. 211-225.

Volkoff, M.C., and Titus, R.G., 2007, Use of otolith microstructure to discriminate stocks of juvenile Central Valley, California, fall-run Chinook salmon: Transactions of the American Fisheries Society, v. 136, no. 1, p. 195-210. [Also available at https://doi.org/10.1577/T05-140.1.].

Wells, B.K., Rieman, B.E., Clayton, J.L., Horan, D.L., and Jones, C.M., 2003, Relationships between water, otolith, and scale chemistries of westslope cutthroat trout from the Coeur d'Alene River, Idaho-The potential application of hard-part chemistry to describe movements in freshwater: Transactions of the American Fisheries Society, v. 132, no. 3, p. 409-424. [Also available at https://doi.org/10.1577/ 1548-8659(2003)132<0409:RBWOAS >2.0.CO;2.].

Wilson, K.H., and Larkin, P.A., 1982, Relationship between thickness of daily growth increments in sagittae and change in body weight of juvenile Sockeye salmon (Oncorhynchus nerka) fry: Canadian Journal of Fisheries and Aquatic Sciences, v. 39, p. 1335-1339. [Also available at https://doi.org/10.1139/f82-179.].

Zhang, Z., Beamish, R.J., and Riddell, B.E., 1995, Differences in otolith microstructure between hatchery-reared and wild Chinook salmon (Oncorhynchus tshawytscha): Canadian Journal of Fisheries and Aquatic Sciences, v. 52, no. 2, p. 344-352. [Also available at https://doi.org/10.1139/ f95-035.]. 


\section{Appendix 1. Tables detailing ANOVA and PERMANOVA results}

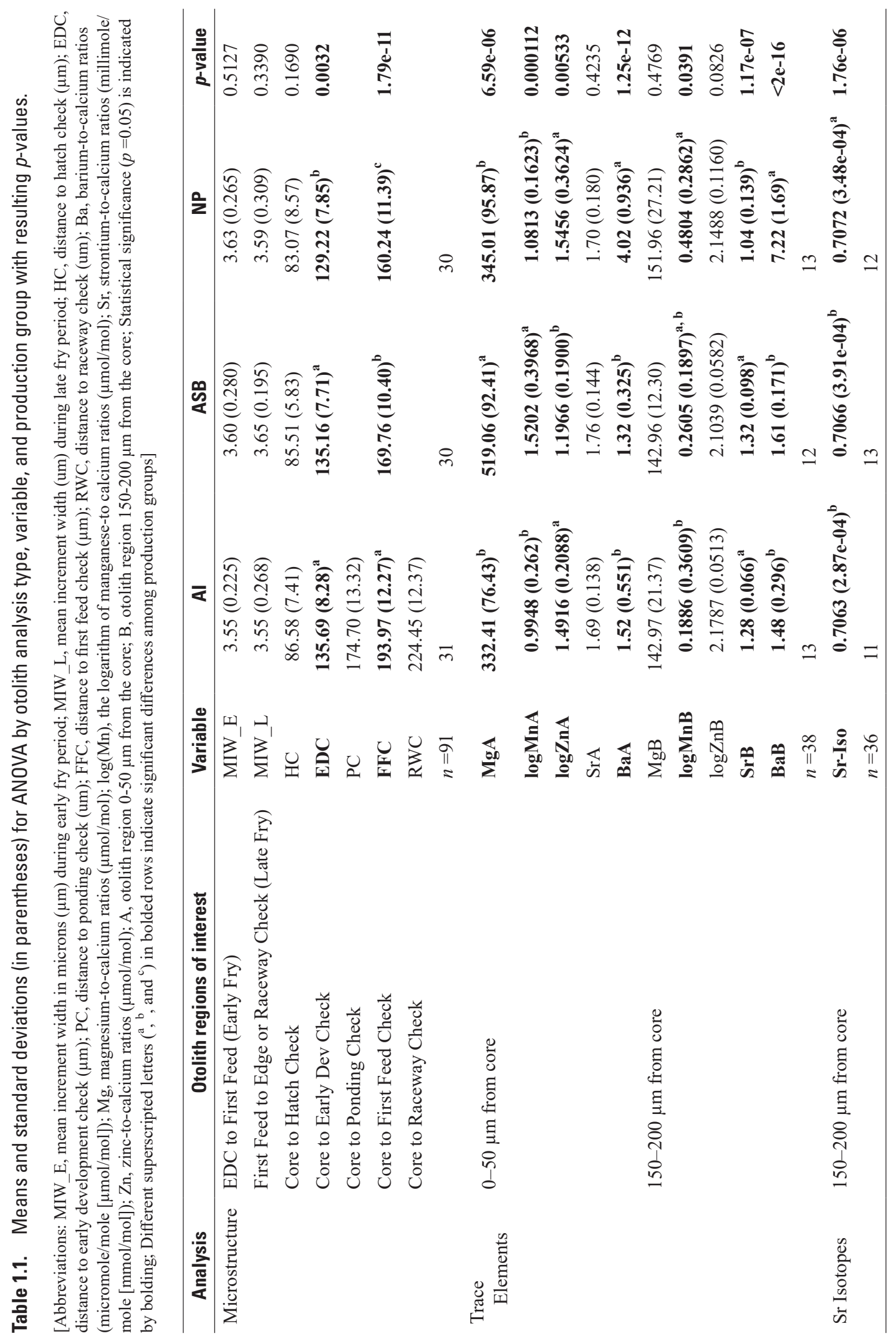


Table 1.2. PERMANOVA results

[Statistical significance $(p=0.05)$ between group distances is indicated by bolding and significance within group distances is indicated by italics]

\begin{tabular}{|c|c|c|c|c|c|}
\hline Data types & Group & Al & ASB & NP & Overall $p$-value \\
\hline \multirow[t]{2}{*}{ MS, TE, Sr-Iso } & $\mathrm{AI}$ & 4.1527 & & & 0.0001 \\
\hline & ASB & $4.6807(0.0001)$ & 4.0219 & & \\
\hline \multirow[t]{2}{*}{ MS, TE } & $\mathrm{AI}$ & 4.0801 & & & 0.0001 \\
\hline & ASB & $4.5723(0.0001)$ & 3.8768 & & \\
\hline \multirow[t]{3}{*}{ MS } & AI & 2.6998 & & & 0.0011 \\
\hline & ASB & $2.6783(0.0884)$ & 2.3958 & & \\
\hline & NP & $3.5616(0.0008)$ & $3.0525(0.029)$ & 3.1590 & \\
\hline \multirow[t]{2}{*}{$\mathrm{TE}$} & AI & 2.8713 & & & 0.0001 \\
\hline & ASB & $3.5843(0.0003)$ & 2.9440 & & \\
\hline
\end{tabular}


Publishing support provided by the U.S. Geological Survey Science Publishing Network, Tacoma Publishing Service Center

For more information concerning the research in this report, contact the

Director, Western Fisheries Research Center

U.S. Geological Survey

6505 NE 65th Street

Seattle, Washington 98115-5016

https://www.usgs.gov/centers/wfrc 


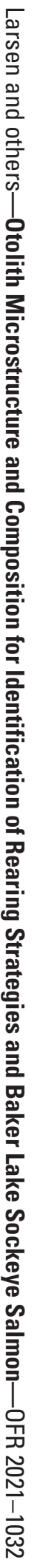

